\title{
A mercantilização do futebol brasileiro: instrumentos, avanços e resistências
}

\author{
Mercantilization of Brazilian football: instruments, advances and resistance
}

\author{
Julio Cesar de Santana Gonçalves ${ }^{1}$ \\ Cristina Amélia Carvalho ${ }^{2}$
}

\begin{abstract}
Resumo
Como fenômeno social, o futebol esteve fundamentalmente subordinado à lógica substantiva assentada em valores e tradições. Entretanto, a atratividade do esporte como gerador de riqueza passou a ser alvo de investimentos e uma fonte de negócios. A partir do momento em que a lógica de mercado se faz presente nas organizações esportivas, ocorre a inserção e a adoção de elementos do universo empresarial na administração dessas organizações. Conceitos e práticas empresariais passam então a vigorar, modificando o discurso de seus dirigentes, bem como as bases de sua legitimação no seu contexto específico. Assim, a ascensão de uma nova lógica de referência traz consigo novos atores, novos procedimentos e categorias antes exclusivas do ambiente das organizações empresariais, como mercadoria, clientela, eficiência, resultado e competitividade.
\end{abstract}

Submetidos à lógica de mercado, os jogadores transformam-se em mercadoria; os torcedores, em consumidores; o jogo, em um ativo financeiro, e o futebol é visto como um grande negócio. As relações centram-se na impessoalidade, são criadas e desenvolvidas estratégias de controle que asseguram o alcance dos objetivos e ações mercantis modernizantes; e a gestão legítima é a que se dá sob os moldes empresariais, e não mais de forma amadora.

Este estudo contribui para a discussão sobre o cenário de mudança social que abrange não só as organizações esportivas, mas também a arte, o cinema e até os espaços públicos, numa tentativa de proporcionar reflexões futuras.

Palavras-chave: futebol; negócio; instituição; mercadoria; ócio.

\begin{abstract}
Brazilian football, as a social phenomenon, had been subordinated to the substantive reason based on values and tradition. However, this sport has become a business due to its attractiveness as a source of wealth. When sport organizations incoporate the logic of the market, the consequence is the adoption of elements from the business world in the administration of these organizations. Managerial concepts and practices become present, changing the management's discourse as well as the basis for their legitimation in their specific context. Thus, the emergence of a new logic of reference produces new actors, new procedures and categories that were exclusive to the environment of entrepreneurial organizations, like goods, customers, efficiency, results and competitiveness. When players are submitted to the logic of the market, they become goods, supporters become consumers, the game becomes a financial asset and the football is seen as a great business. Relations are based on impersonality, strategies of control are developed since they assure the achievement of objectives, as well as modernizing market actions, and the legitimate management is the one wich is based on professionalism. This study contributes to the discussion on the scenario of social change wich includes not only sport organizations but also arts, cinema and even public spaces, with the purpose of trying to provide future reflexions.
\end{abstract}

Keywords: football, business, institutions, goods; leisure.

\footnotetext{
${ }^{1}$ Mestre em Administração pelo Programa de Pós-Graduação em Administração da Universidade Federal de Pernambuco - PROPAD/UFPE. Endereço: UFPE - Av. Prof. Moraes Rego, 1235 - Cidade Universitária, Recife - PE - Brasil - CEP: 50670-901. E-mail: jcesargoncalves@bol.com.br.

${ }^{2}$ Doutora em Ciências Econômicas e Empresariais Universidade de Córdoba - Espanha. Professora do PROPAD/UFPE. Endereço: UFPE - Av. Prof. Moraes Rego, 1235 - Cidade Universitária, Recife - PE - Brasil CEP: 50670-901. E-mail: cris_carvalho@uol.com.br.

Artigo recebido em março de 2006 e aceito para publicação em abril de 2006.
} 


\section{Introdução}

Na sua origem, o futebol brasileiro se caracterizava essencialmente por seu caráter lúdico e pela centralidade de valores como a construção de laços afetivos e de identidade entre os indivíduos. As características centrais do futebol eram o lazer, a diversão, o ócio e a criação de laços de pertencimento entre os indivíduos (ELIAS; DUNNING, 1995). Essas eram as motivações centrais para a aglutinação das pessoas nos grupos, e sinalizavam para a adesão a um conjunto específico de valores que se expressavam no conjunto de relações e atitudes dos seus membros (SEVCENKO, 1994). Originalmente, um esporte elitista, o futebol é, no século XXI, motivo de mobilização e de expressão de um grande número de pessoas das diversas classes sociais.

No entanto, ao longo do tempo, várias transformações no ambiente das organizações esportivas exerceram forte influência na sua forma de gestão. Principalmente, nas últimas três décadas, o futebol atraiu novos tipos de organizações (instituições financeiras, empresas de marketing esportivo etc.) e passou a movimentar grandes cifras, como não ocorria há algumas décadas atrás. Dos US\$250 bilhões anuais que, estima-se, o futebol movimenta no mundo, o Brasil contribui com US\$32 bilhões (CBF NEWS, 2004). Este esporte perdeu seu caráter lúdico, cedendo lugar a uma lógica mercantilista, tornando-se um futebol-negócio (CARVALHO, 2001 e 2003).

A inserção da lógica de mercado como discurso dominante em múltiplos setores da sociedade conduz a mudanças nas organizações, das quais não estão isentas as organizações esportivas. Meyer e Rowan (1991) defendem que para interpretar os modelos estruturais, as formas de gestão e os processos de tomada de decisão adotados pelas organizações é necessário compreender o contexto que as envolve. No cenário do futebol essa assertiva mostra-se adequada na medida em que seus contextos de referência e os valores aos quais ele se subordina se alteraram profunda e velozmente nas últimas décadas.

A partir da implantação da lógica de mercado nas organizações esportivas, ocorre a inserção e a adoção de elementos do universo empresarial e de seus negócios na administração dessas organizações. Conceitos e práticas empresariais se impõem e modificam o discurso de seus dirigentes, bem como as bases de sua legitimidade em seu contexto específico. A ascensão de uma nova lógica de referência traz consigo novos atores, procedimentos e categorias antes exclusivos do ambiente das organizações empresariais, como empresários, mercadoria, clientela, eficiência, resultado e competitividade. Assim como o cinema ou as artes plásticas, hoje, o esporte é tratado como uma indústria que envolve diversas organizações - públicas, privadas ou não lucrativas, que provêm produtos e serviços -, bem como organizações profissionais que contratam atletas, cineastas, atores, artistas plásticos ou curadores (pagando por seu trabalho), além das empresas de entretenimento, especialmente a mídia televisiva.

Segundo Slack (1997, p.5), uma organização esportiva é "uma entidade social envolvida na indústria do esporte, que tem objetivos e dispõe de uma estrutura definida e com fronteiras relativamente identificáveis". Nesse contexto, estão os clubes de futebol. Hoje, eles existem com o propósito de obter lucros, vencer campeonatos, desenvolver a prática do desporto etc., dispondo de uma estrutura de atividades relativamente definidas, com áreas como marketing, finanças, recursos humanos e departamentos de esportes que se relacionam para seus objetivos sejam alcançados. $\mathrm{O}$ aumento considerável do número de praticantes de esportes no mundo, o surgimento de novas modalidades esportivas e os investimentos da mídia têm evidenciado que o esporte, pela sua crescente relevância econômica, tornou-se um dos grandes ativos financeiros para inúmeras empresas privadas (SANTOS et al, 2004).

Diante da importância econômica que se tem atribuído ao futebol, somada à inserção da lógica de mercado nesse setor, assume-se que os aspectos econômicos, políticos, culturais e sociais permeiam essa prática desportiva (DACIN, 1999). O futebol transformou-se numa imensa indústria que movimenta milhões no mundo inteiro. Produziram-se espetáculos esportivos, surgiram os grandes atletas profissionais e os mitos esportivos. Submetido à lógica de mercado, os jogadores transformaram-se em mercadoria, os torcedores em consumidores, o 
jogo num ativo financeiro, e o futebol é visto como um grande negócio (GONÇALVES; MAGALHÃES FILHO; ALCÂNTARA, 2003).

Este artigo procura analisar as mudanças ocorridas no campo do futebol, dada a inserção e expansão da lógica de mercado como discurso dominante e a implantação de um modelo empresarial de gestão. Assim, parece apropriado utilizar o conceito de desinstitucionalização proposto por Oliver (1992), que o define como um processo de mudança institucional pelo qual a legitimidade de uma estabilidade ou prática organizacional institucionalizada se degrada ou toma uma forma de descontinuidade.

Deve ser salientado que este artigo está vinculado a uma pesquisa de maior vulto, intitulada "Configuração do campo da cultura no contexto da incorporação da lógica mercantil e os novos atores organizacionais", realizada pelo grupo de pesquisa Observatório da Realidade Organizacional. Vale ressaltar, também, a relação que este texto tem com estudos anteriores realizados no âmbito do Observatório (CARVALHO, GONÇALVES e ALCÂNTARA, 2003; GONÇALVES; CARVALHO; ALCÂNTARA, 2004; GONÇALVES; MAGALHÃES FILHO; ALCÂNTARA, 2003).

\section{Metodologia}

Neste estudo, a pesquisa qualitativa histórica foi adotada como estratégia metodológica fundamental, o nível de análise é o campo organizacional e a unidade de análise, o futebol brasileiro como instituição. A adoção de uma abordagem qualitativa (TRIVIÑOS, 1995) dos dados primários e secundários coletados visou possibilitar a descrição e análise das principais mudanças ocorridas no contexto do futebol brasileiro diante da lógica de mercado e da adoção de um modelo empresarial. Para tanto, foi empregado um tipo específico de método histórico, o historiográfico interpretativo (TUCHMAN, 1994).

Os métodos históricos permitem uma análise mais aprofundada de questões contextuais que envolvem um determinado fenômeno social, e por isso são apropriados para se chegar a uma resposta a indagações do tipo explicativas. Neste estudo, foi empregado o tipo historiográfico interpretativo, cuja finalidade é compreender os fatos ao longo do tempo e através do espaço, objetivando construir uma narrativa que explique satisfatoriamente o fenômeno estudado (p.315).

Dessa forma, diante da proposta deste estudo de focar a compreensão de um processo de desinstitucionalização do campo do futebol no Brasil - e, conseqüentemente, procurar desvendar o "por quê" e o "como" essa transformação ocorre ao longo do tempo com a incorporação de uma nova lógica de ação, que é a de mercado -, e mediante a adoção de um modelo empresarial de gestão, acredita-se que esse método seja adequado. Com o fim de clarificar a análise em apreço neste estudo, foram empregadas ilustrações para os principais elementos que caracterizam o fenômeno a ser pesquisado (MARCONI; LAKATOS, 1990 p.47).

A coleta de dados se fundamentou, sobretudo, na obtenção de dados secundários e na aplicação de questionário, via correio eletrônico, a informantes-chave (MARCONI; LAKATOS, 1990). Por sua vez, a seleção dos informantes-chave foi feita por uma abordagem subjetiva, através de uma amostragem não probabílistica do tipo bola de neve (COOPER; SCHINDLER, 2003). Neste estudo, esse tipo de técnica foi utilizado porque os respondentes seriam mais facilmente localizados por meio de redes de referência, dada a abrangência desta pesquisa e o tipo de sujeitos selecionados, com notório conhecimento sobre o tema.

A interpretação dos discursos obtidos nos dados primários e secundários permitiu verificar os pressupostos estabelecidos no estudo e corroborar a explicação teórica. A análise interpretativa aplicada aos questionários e documentos facultou a identificação de conexões entre os discursos e assim ofereceu uma compreensão mais abrangente das dimensões envolvidas na pesquisa. 


\section{Mudança institucional: processos de desinstitucionalização e reinstitucionalização}

Até à adoção da concepção institucional, as organizações eram vistas como um mero sistema de produção e de trocas - e suas estruturas, como produto de suas tecnologias e transações -, e caracterizadas pelas relações de dependência. Quanto ao ambiente, este era concebido unicamente como "ambiente-tarefa", caracterizado como estoque de recursos, fonte de informação, local de competição e celeiro de parceiros.

A preocupação em se compreender a influência que elementos técnicos exercem sobre as organizações tem sido discutida desde as abordagens clássicas da administração. Entretanto, as organizações que não estavam subordinadas a lógicas técnicas não podiam ser compreendidas à luz dessas abordagens teóricas. Dessa forma, com a teoria institucional, também passou a ser considerada a influência de elementos institucionais sobre o desempenho e a sobrevivência organizacionais.

Meyer e Rowan (1991) - cujo texto original data de 1977 - foram os pioneiros na distinção entre dois tipos de ambiente, demonstrando que as pressões ambientais variam de acordo com cada tipo de ambiente. Foi então, que se passou a considerar a existência de dois tipos de ambiente distintos: o técnico e o institucional. O primeiro, conceituado genericamente como "ambiente tarefa", provê meios e fins para os produtos e serviços gerados pela organização. Nesse ambiente, as organizações são recompensadas tendo em vista que exercem controle eficiente e efetivo sobre os processos de trabalho. Já o ambiente institucional provê os fatores cognitivoculturais, como normas e valores a que as organizações se conformam para terem legitimidade (ANDRADE FILHO; MACHADO-DA-SILVA, 2002; SCOTT, 1998; SCOTT; MEYER, 1991).

Cabe salientar que, embora com definições diferenciadas, os ambientes técnico e institucional não são mutuamente excludentes. A distinção entre eles não implica dicotomia, pois formam um continuum ao longo do qual situam-se diferentes pressões e requisitos. Ao se selecionar apenas um desses ambientes como base de interpretação tem-se uma visão parcial da realidade, pois em todos os tipos de organizações podem ser encontradas características inerentes aos dois tipos de ambiente (CARVALHO; VIEIRA, 2003).

Dentro dos pressupostos centrais da perspectiva institucional destacam-se os conceitos de instituição e de institucionalização, próprios da sociologia geral. Segundo Jepperson (1991), uma instituição representa uma ordem social ou um padrão que atingiu uma certa estabilidade ou propriedade. Todas as instituições são constituídas por programas ou regras que criam identidades, cada uma com seus scripts, significados, existência e propósitos, que devem ser levados em conta.

Jepperson (1991) chama a atenção para o fato de que a identificação de uma instituição depende do contexto de análise e da dimensão que ela ocupa num relacionamento. Berger e Luckmann (1976) tratam da origem da instituição como o resultado final do processo de institucionalização, definida por Jepperson (1991) como o processo pelo qual uma instituição se reproduz e revela um padrão social. As instituições, então, são

produto da construção humana e o resultado de ações propostas por indivíduos instrumentalmente guiados pelas próprias forças institucionais por eles interpretadas, sugerindo, portanto, um processo estruturado e ao mesmo tempo estruturante, que não é necessariamente racional e objetivo, mas fruto de interpretações e subjetividades. (VIEIRA; CARVALHO, 2003, p.3)

Contudo, elementos deslegitimados podem também se tornar institucionalizados (por exemplo, crime organizado, corrupção política, fraude etc.), pois vão progressivamente construindo uma nova legitimidade. Acredita-se que algo é legítimo ou ilegítimo de acordo com o seu contexto. Assim, a legitimidade e a ilegitimidade podem ser sinais de institucionalização, o que constitui uma de suas propriedades (JEPPERSON, 1991).

Por sua vez, a inexistência de uma instituição se deve à ausência de ordem ou de sua reprodução (entropia social), à não geração de conseqüências da interação social (mesmo que repetida e persistente) e à reduzida parti- 
cipação e intervenção dos atores sociais na ação e construção de um padrão social de forma duradoura (JEPPERSON, 1991).

Oliver (1992) salienta que autores da perspectiva institucional negligenciaram a existência de mudanças em organizações como, por exemplo, a mudança no status quo institucional, o abandono de hábitos e costumes e a deterioração do consenso organizacional em torno do valor de uma atividade institucionalizada. Desconsiderava-se que processos e práticas institucionalizados poderiam ser reavaliados e rejeitados e, conseqüentemente, serem desinstitucionalizados.

Para Berger e Luckmann (1976), a institucionalização não é um processo irreversível, a despeito do fato das instituições, uma vez formadas, terem a tendência a perdurar. Eles afirmam que "por uma multiplicidade de razões históricas, a extensão das ações institucionalizadas pode diminuir. Pode haver desinstitucionalização em certas áreas da vida social." (p.113)

A deslegitimação de uma prática ou procedimento outrora institucionalizado é denominada desinstitucionalização. Ela implica uma nova legitimidade (DAVIS; DIEKMANN; TINSLEY, 1994, ROWAN, 1982), e, segundo Oliver (1992), refere-se ao processo pelo qual a legitimidade de uma estabilidade ou prática organizacional institucionalizada se degrada ou sofre uma descontinuidade. Configura-se, então, um tipo de mudança institucional que pode ser entendida como produto de algumas classes de choques exógenos que rompem uma ordem estabilizada (BECKERT, 1999; CLEMENS; COOK, 1999).

Ao tratar do institucionalismo na análise organizacional, Jepperson (1991) salienta a existência de quatro tipos de mudança institucional:

- a formação institucional - que se caracteriza pela quebra do estado de entropia social, ou seja, de "equilíbrio"/harmonia social;

- desenvolvimento institucional - que diz respeito à mudança de uma forma institucional;

- a desinstitucionalização - que se refere à ruptura de uma forma institucional, com o desencadeamento de um processo de entropia social; e

- a reinstitucionalização - que envolve a ruptura de uma forma institucional e a entrada noutra completamente diferente, em termos de princípios, valores, regras, normas e procedimentos.

O autor considera ainda que as instituições podem se desenvolver e sucumbir às contradições com seus ambientes, com outras instituições ou com padrões elementares de comportamento social. Essas contradições (ou choques exógenos do ambiente) podem forçar uma mudança institucional, devido à criação de barreiras que impeçam a reprodução das normas, procedimentos e valores compartilhados numa determinada instituição, o que conduziria uma modificação ou até a destruição dessa instituição.

Oliver (1992) identificou um grupo de fatores organizacionais e ambientais que predizem e moderam o processo de desinstitucionalização. Ao contrário da ênfase que a teoria institucional atribui à persistência cultural e à resistência de comportamentos organizacionais institucionalizados, essa autora sugere que, sob uma variedade de pressões, tais comportamentos serão susceptíveis à dissipação, rejeição ou substituição. Assim, a desinstitucionalização, como um tipo de mudança institucional, implica a existência de mecanismos/elementos de resistência. A figura 1 sumariza os fatores preditores e moderadores do processo de desinstitucionalização. 


\section{Figura 1}

\section{Pressões para desinstitucionalização}

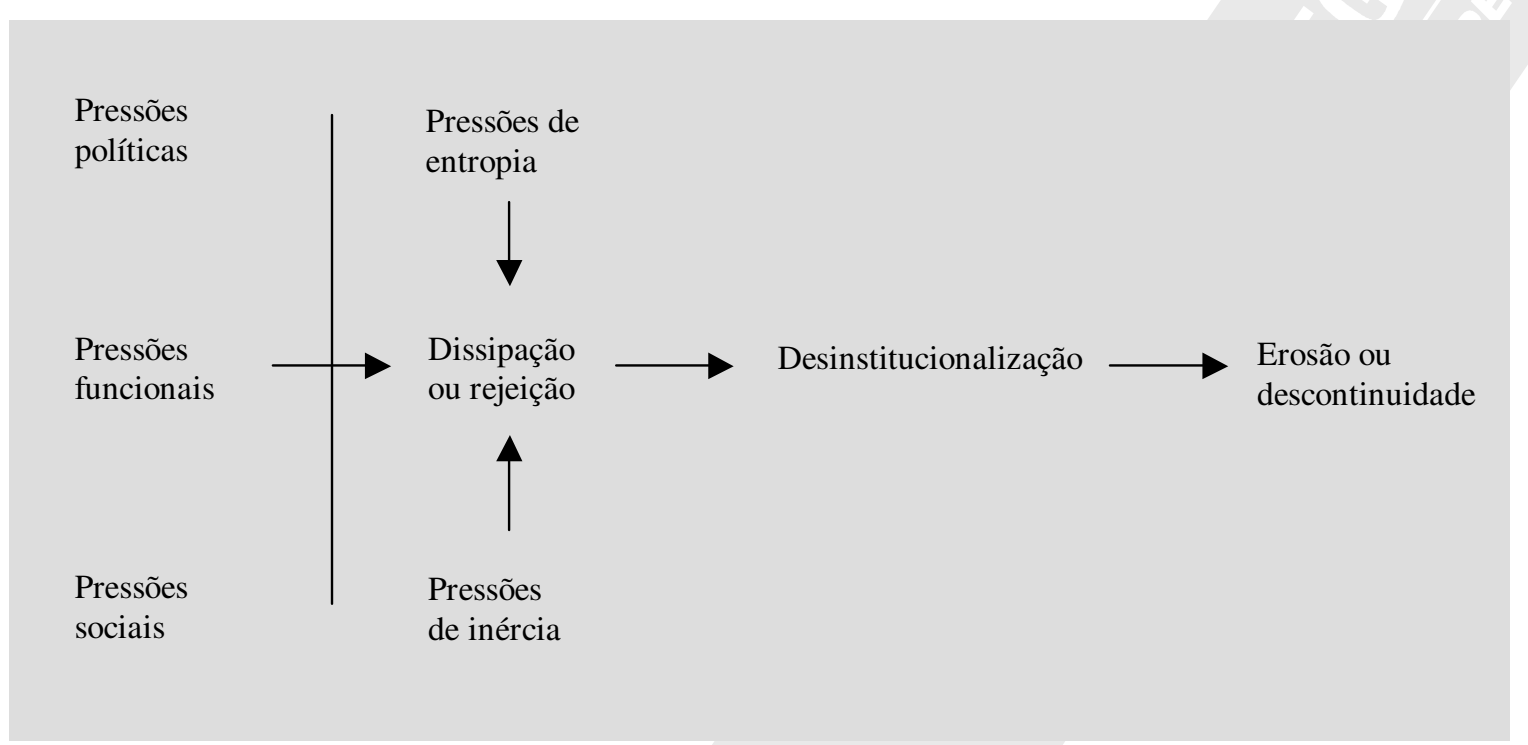

Fonte: adaptado de Oliver (1992, p.567).

Os mecanismos políticos, funcionais e sociais são determinantes para esse processo. As pressões de entropia e de inércia moderam o nível de desinstitucionalização. Enquanto a entropia organizacional tende a acelerar o processo de desinstitucionalização, a inércia organizacional tende a impedi-la. Juntos, determinam a probabilidade de dissipação ou rejeição de uma prática organizacional institucionalizada. Para Oliver (1992), enquanto aquela se refere ao grau de deterioração na aceitação/aprovação e no uso de uma prática institucionalizada específica, esta está relacionada à percepção da validade de uma atividade, costume ou tradição.

O quadro 1 mostra os indicadores empíricos para a desinstitucionalização em nível organizacional e do ambiente.

Pressões políticas resultantes, por exemplo, de crises de performance tendem a causar dissensões e conflitos internos, além de deteriorarem o consenso entre organizações de um mesmo campo ou setor, enfraquecendo os mecanismos de socialização. Configura-se, então, um processo de desinstitucionalização, pois o que é institucionalizado resulta do compartilhamento de normas e valores por uma coletividade, durante um período, e de certo grau de estabilidade e de concordância entre os membros de uma organização. 
Quadro 1

Preditores empíricos da desinstitucionalização

\begin{tabular}{cc}
\hline FATORES INTRA-ORGANIZACIONAIS & RELAÇÕES ORGANIZAÇãO/AMBIENTE \\
\hline Mudanças na distribuição política & Pressões ambientais competitivas \\
\hline Alta diversidade da força de trabalho & Aumento da competição por recursos ou domínios \\
\hline Crises de performance & Aumento das pressões por inovação \\
\hline Realocações de poder & Pressões sociais do ambiente \\
\hline Ameaça de obsolescência & Mudanças nas regulações governamentais \\
\hline Mudanças na necessidade funcional & Mudanças nos valores sociais \\
\hline Aumento da especificidade técnica & Ocorrências externas aleatórias \\
\hline Melhor definição das metas & Eventos e dados dissonantes \\
\hline Mudanças no consenso social & Mudanças nas relações com os constituintes \\
\hline Aumento do turnover ou das sucessões & Declínio da dependência externa \\
\hline Fraqueza nos mecanismos de socialização & Eliminação de incentivos \\
\hline Alianças e fusões díspares culturalmente & Elevação de padrões de eficiência \\
\hline Alta diversificação, dispersão ou diferenciação &
\end{tabular}

Fonte: Oliver (1992, p.579).

Da mesma forma, o aumento da pressão sobre uma organização para que adote práticas inovadoras e reduza ou altere a dependência em relação a constituintes ambientais específicos também indicam esse tipo de mudança institucional. Além do que, quando a especificidade técnica de uma operação organizacional é aumentada há, também, uma tendência para que ocorra uma entropia social. Eventos e dados dissonantes no ambiente das organizações podem levar a uma descrença na utilidade econômica da organização, desestabilizando uma determinada ordem e causando a ruptura de uma prática institucionalizada.

Por outro lado, descontinuidades históricas implicam desestabilidade e a não-reprodução de significados compartilhados. As pressões sociais e, conseqüentemente, a fragmentação normativo-social levam à perda de consenso cultural entre os membros de uma organização em relação a esses significados. A alteração das normas e valores institucionais e as mudanças nas interações entre os parceiros no campo contribuem para a erosão e dissipação de normas e práticas institucionalizadas, implicando uma nova legitimidade. Contudo, deve ser salientado que nesse processo há focos de resistência por parte de alguns atores do campo que tentam preservar os valores anteriormente institucionalizados.

Greenwood e Hinings (1996) afirmam que a mudança institucional pode ser revolucionária ou evolucionária. O que a define é a escala e o ritmo da ruptura e do ajuste organizacional. Assim, enquanto a mudança evolucionária é lenta e gradual, a mudança revolucionária ocorre rapidamente e afeta, simultaneamente, todas as partes do objeto considerado, precipitando então a adaptação a ser feita. Essas mudanças são tidas como desinstitucionalizadoras quando geram a adoção de novas ideologias e comportamentos num determinado sistema social e econômico (PEREIRA; FONSECA 1997, apud PINTO; OLIVEIRA 2002).

Pinto e Oliveira (2002) salientam que a incidência dessas mudanças varia conforme o setor institucional, por causa da diferença de estruturas, especialmente, naquelas em que há alto grau de integração e insulamento. Greenwood e Hinings (1996) ressaltam que as mudanças implementadas nas organizações, bem como os tipos de reação resultantes (aceitação ou resistência), são bem melhor compreendidos quando se leva em conta categorias analíticas subjacentes (por exemplo, crenças, valores e interesses) aos seus processos formais e técnicos. Diante do exposto, podemos dizer que

Os processos de "desinstitucionalização" podem então ocorrer em resposta a questionamentos internos referentes à adequação de práticas e procedimentos às exigências ambientais, que poderão permitir a um grupo de atores sociais, cujos interesses estejam em desacordo com a estrutura, a ela se opor conscientemente ou explorar suas fraquezas. Nesse processo, o colapso resultante expõe a organiza- 
ção a um estado de vulnerabilidade, criando um vácuo institucional, passível de ser preenchido somente por meio de redefinição e posterior relegitimação de novas concepções e operações, o que caracteriza um processo de "reinstitucionalização". (PINTO; OLIVEIRA, 2002, p.9)

Beckert (1999, p.788), ao tratar das noções de agência, empreendedorismo e mudança institucional, salienta que a reinstitucionalização é um "processo de adaptação que conduz ao reembricamento ${ }^{3}$ de práticas sociais". Neste estudo, entende-se embeddedness como a inserção de uma organização ou instituição na estrutura social, ou ainda como imersão social (DACIN, 1999). Dessa forma, a reinstitucionalização é um tipo de mudança institucional verificada quando há a adoção de diferentes normas e valores, substituidoras de outras existentes num determinado campo ou setor.

\section{A desinstitucionalização do futebol brasileiro}

A apreensão do processo histórico em que foi produzida uma instituição é imprescindível para sua adequada compreensão, pois, como afirma Selznick (1971, p.121), "o estudo das instituições é, em alguns casos, comparável ao estudo clínico da personalidade. Requer uma ênfase nas suas origens históricas e etapas de crescimento". Ao se estudar uma instituição, é necessário compreendê-la no seu todo e como se transformou, na medida em que evoluíram as novas formas de tratamento de um ambiente em mudança. Berger e Luckmann (1976, p.79) afirmam ainda que

As instituições implicam a historicidade e o controle. As tipificações recíprocas das ações são construídas no curso de uma história compartilhada. Não podem ser criadas instantaneamente. As instituições têm sempre uma história, da qual são produtos. É impossível compreender adequadamente uma instituição sem entender o processo histórico em que foi produzida.

O futebol começou a se organizar no Brasil, assim como em boa parte do mundo, na virada do século XIX para o XX, como atividade civil, prática lúdica, que contribuía para a educação e a saúde de seus praticantes, e como forma de lazer comunitário. Estava baseado na livre iniciativa da sociedade civil e na livre organização.

É verdade que podemos ver ainda, focos de lazer, ócio e diversão em jogos realizados em campos de várzea em áreas urbanas e em áreas rurais. Mas, esse cenário em que os campos de várzea e os terrenos baldios procuram dar o "tom" do futebol-arte - na periferia ou nos clubes sociais da elite, ao final da partida, vencedores e perdedores se reúnem para confraternizar e estreitar os laços de identidade coletiva -, atualmente, está limitado a pequenos casos em zonas periféricas. Hoje, o futebol é tratado como produto, configurando uma oportunidade de se fazer negócio.

Por volta da segunda metade do século XX, a exploração e a promoção de eventos baseados no futebol, praticado por atletas profissionais, tornou-se atividade econômica organizada e negocial de vulto. Transformou-se, assim, numa atividade com características fáticas de ato comercial, como a venda de espetáculos e de suas transmissões por mídia eletrônica, a exploração de marcas e a exploração da prestação de serviço de praticante profissional com o objetivo de resultado econômico. A sobreposição de elementos técnicos aos institucionais (sem negar a importância destes) é uma das características presentes, hoje, no cenário do futebol brasileiro.

\section{As relações organização-ambiente}

Em seu estudo sobre o processo de desinstitucionalização, Oliver (1992) salienta a existência de preditores ao nível das relações organização/ambiente. Tais indicadores empíricos podem ser identificados no atual campo do futebol brasileiro, o que de certa forma justifica a sobreposição dos elementos técnicos aos institucionais na

\footnotetext{
${ }^{3}$ Re-embedding, no original (BECKERT, 1999).
} 
"instituição futebol”. Mais adiante, tais elementos são identificados e analisados, considerando-se a influência que a lógica de mercado e a adoção de um modelo empresarial de gestão exercem sobre as transformações pelas quais passa o futebol brasileiro.

No atual cenário do futebol brasileiro, podemos perceber pressões ambientais competitivas no que diz respeito à crescente disputa por recursos e por inovações, tendo em vista o impacto econômico que incide, hoje, no desporto profissional, em face da presença marcante da "profissionalização", da "comercialização" e da sua interrelação com os meios de comunicação. São exemplos dessas pressões, a disputa por profissionais credenciados e com competência gerencial (como, por exemplo, dirigentes-executivos, cronistas especializados e consultores de marketing esportivo), a obtenção de novas fontes de recursos (como a cessão de direitos federativos sobre a imagem do atleta e verbas de televisão), a inserção de novas estratégias de ação (como parceria e marketing esportivo) e as arenas multiuso.

Álvaro Melo Filho, membro da Fifa e da Comissão de Estudos Jurídicos Desportivos do Ministério de Esporte, afirma

Com efeito, é inegável a economización del deporte ou sportbusiness gerando fluxos monetários nos mais variados âmbitos: artigos desportivos (chuteiras, vestuário, bolas etc.), espetáculo desportivo (cobrança de ingressos para assistir às competições), retransmissões desportivas (direito de retransmissão por TV aberta, canais fechados ou pelo sistema pay per view), mercado de trabalho desportivo (atletas, técnicos, preparadores físicos, árbitros etc.), publicidade e patrocínio (nas arenas, praças $e$ estádios desportivos), imprensa desportiva (comentaristas, locutores, repórteres, crônica especializada etc.), infra-estrutura e equipamentos desportivos, medicina desportiva (médicos, psicólogos, fisioterapeutas, massagistas etc.) e seguros formalizados para cobrir os riscos da prática desportiva e dos espectadores, são apenas alguns exemplos. (MELO FILHO, 2004, p.93)

Pressões sociais do ambiente sobre as organizações do campo do desporto, mediante mudanças nas regulações governamentais e nos valores sociais, também constituem preditores das transformações pelas quais passa o futebol brasileiro, ao longo de sua história. É inegável o papel do Estado como agente dessas mudanças, mediante alterações no marco legal do futebol. Como exemplo, cita-se a promulgação da Lei nº 9.615, de 24-3-1998, comumente denominada "Lei Pelé", que adota a obrigatoriedade da transformação dos clubes sociais em "clubes-empresa".

Concomitantemente, percebe-se a fragmentação de valores sociais outrora fortemente legitimados na "instituição futebol". Da integração e convívio social por parte dos participantes dessa instituição, passou-se para o vislumbrar de um "mercado potencial e uma oportunidade de negócio". Hoje, o torcedor é visto como "consumidor" por grande parte dos gestores e entidades futebolísticas; o jogador é tido como "mercadoria" para os clubes e o futebol como "produto e ativo financeiro" para os parceiros envolvidos nesse "jogo/empreendimento".

Recentemente, foi lançado o Atlas do esporte no Brasil, comercializado em CD-ROM e disponível na Internet. O Conselho Federal de Educação Física (Confef), idealizador do atlas, contou com a participação do Ministério dos Esportes, do Comitê Olímpico Brasileiro (COB), da Escola de Administração Pública e de Empresas da Fundação Getúlio Vargas (Ebape/FGV), do Serviço Social da Indústria (Sesi), do Serviço Social do Comércio (Sesc), da Confederação Brasileira de Clubes, Federação das ABBs (Fenabb) e da Associação Cristão de Moços (ACM).

Para Lamartine DaCosta, professor de pós-graduação em educação física da Universidade Gama Filho e pesquisador ligado à Academia Olímpica Internacional e ao Comitê Olímpico Internacional (COI), os objetivos desse atlas são avaliar os aspectos econômicos do esporte e sistematizar os dados para orientar investimentos do setor privado (que precisa desses dados para planejar seus "negócios"), além de facilitar pesquisas. 
Oliver (1992) considera que dentre os fatores preditores de um processo de desinstitucionalização (a nível das relações organização/ambiente), estão ocorrências externas aleatórias, visualizadas em eventos e dados dissonantes em relação a um contexto até então institucionalizado/legitimado. No atual cenário do futebol brasileiro, essa assertiva se revela quando se percebe a existência de fatos dissonantes, como:

- realização de Comissões Parlamentares de Inquérito (CPI) para investigar irregularidades nas práticas e na gestão de entidades futebolísticas (exemplos: CBF, clubes e federações); e

- constatações de que houve lavagem de dinheiro por parte da Parmalat, quando da parceria mantida com o clube Palmeiras (SP), o que contribuiu, também, para a criação de leis de moralização do futebol e fiscalização mais efetiva pelo Ministério Público.

Considerando os parceiros estratégicos do universo do futebol como a mídia televisiva, as empresas privadas, os investidores internacionais, os bancos etc., percebe-se que, ante a percepção de que o futebol é uma grande indústria que movimenta milhões e com a qual se pode obter melhoria de suas imagens institucionais, tais organizações decidem (e se predispõem a) investir em grandes clubes que contem com grande número de torcedores, e com representatividade no cenário nacional e até internacional. É o caso das relações de patrocínio de camisas, que normalmente rende aos cofres dessas empresas significativos "ganhos de mercado" (market share), que as levam a renovar os seus contratos.

Entretanto, tais questões estão, de certa forma, condicionadas ao fato de que os clubes demonstrem profissionalismo na gestão e na condução do "empreendimento". Portanto, exige-se maior padrão de eficiência (verificável por controles estatísticos), balanços, competência gerencial, presença de profissionais devidamente credenciados etc., sob risco de remoção de incentivos; ou seja, de não haver renovação de contrato ou permanência da parceria.

Na história do futebol brasileiro, nota-se uma certa diminuição da dependência financeira do clube em relação aos recursos oriundos de bilheterias. É inegável a importância das bilheterias para a arrecadação de recursos dos clubes, sobretudo para os que têm grande torcida. Porém, hoje, diante da expansão da lógica de mercado e mediante a exigência de critérios empresariais de gestão, há inúmeras outras fontes alternativas de recursos, como cessões de direito sobre a marca do clube, cessões de direitos federativos sobre a imagem do atleta, verbas de televisão, patrocínio e contratos de marketing e parceria. Destas, salienta-se que, atualmente, a maior parte da receita de um clube de futebol brasileiro advém dos direitos de transmissão pela televisão.

A elevação de padrões de eficiência, a remoção de incentivos e o declínio da dependência externa configuram mudanças nas relações com os constituintes do campo do desporto. Somados aos indicadores apresentados anteriormente constituem preditores das transformações pelas quais passa o futebol brasileiro, pela transposição de sua lógica de ação.

O quadro 2 sintetiza as questões até aqui apresentadas no atual cenário do futebol brasileiro. 


\section{Quadro 2 \\ Relações organização/ambiente \\ como preditores do processo de desinstitucionalização do futebol brasileiro}

\section{RELAÇÕES ORGANIZAÇÃO/AMBIENTE}

Pressões sociais do ambiente

\section{INDICADORES}

Aumento da competição por recursos ou domínios e das pressões por inovação

Disputa por profissionais credenciados e com competência gerencial. Exemplo: dirigentes executivos e consultores de marketing esportivo.

Obtenção de novas fontes de recursos, como a cessão de direitos sobre a marca

Inserção de novas estratégias de ação, como a construção de estádios-arena de entretenimento

Mudanças nas regulações governamentais

Estado exerce papel como agente de mudança, mediante alterações no marco legal. Exemplo: Lei Pelé institucionaliza o "clube-empresa"

Mudanças nos valores sociais

Da integração e convívio social entre os participantes para o vislumbrar de um "mercado potencial e uma oportunidade de negócio"

Torcedor visto como "consumidor", o jogador como "mercadoria" e o futebol como "produto"

Eventos e dados dissonantes

Realização de CPIs do futebol para investigar irregularidades na gestão e desvios de dinheiro

A lavagem de dinheiro da Parmalat, por exemplo, levou à criação de leis de moralização do futebol Declínio da dependência externa

Diminuição da dependência financeira do clube estritamente dos torcedores. Hoje, as fontes de financiamento são inúmeras; incluem cessão de direitos, verbas de televisão etc.

Elevação de padrões de eficiência e eliminação de incentivos

Mudanças nas relações com os constituintes

Necessidade de que os clubes e entidades futebolísticas adotem estratégias modernizantes e de gestão profissional. Exemplo: sistemas de planejamento e de gestão de recursos, contratação de consultores esportivos e diversificação das fontes de recursos

Tal discurso é determinado pelo fato de que quanto menor o padrão de eficiência, menores os incentivos. Pode até implicar a não renovação de contratos/parcerias

Fonte: elaborado pelos autores

\section{Fatores intra-organizacionais}

Além dos preditores de um processo de desinstitucionalização no âmbito das relações organização/ambiente, Oliver (1992) apresenta fatores intra-organizacionais desse processo. Tais indicadores empíricos propostos por essa autora foram percebidos no atual campo do futebol brasileiro, o que contribui para justificar a supervalorização da dimensão comercial do futebol em relação a sua dimensão valorativa. 
Podemos dizer que, com a profissionalização do futebol, os clubes ampliaram seus estádios - e, desde então, vêm comercializando produtos durante as partidas -, ocorrendo, até hoje, mudanças na distribuição política dessas entidades esportivas. Novos profissionais são necessários, como preparadores físicos, roupeiros, massagistas, médicos, advogados - todos dedicando-se parcial ou exclusivamente a um clube -, o que constitui alta diversidade da força de trabalho e realocações de poder. Hoje, essa diversidade também deve abranger, segundo o discurso dominante, a presença de profissionais credenciados para gerir o "negócio-futebol". Segundo afirmou numa entrevista em 27-10-2004, o ministro da Ciência e Tecnologia do governo Lula, Eduardo Campos, "o tempo artesanal da atividade já se foi. O futebol atual exige dos clubes o conhecimento e a prática exercidas pelas empresas mais eficientes e eficazes."

No campo do futebol brasileiro, também são observadas mudanças na necessidade funcional, as quais podem ser percebidas tanto pela maior especificidade técnica, quanto pelo estabelecimento de metas mais claras. Nesse sentido, os discursos prevalecentes nas entrevistas e nos dados primários e secundários sinalizam a crença de que a sobrevivência de um clube de futebol está ligada a uma gestão fundamentada em critérios profissionais.

Os clubes precisam ter visão estratégica de longo prazo para que o país seja consumidor, e não mais exportador de futebol. [...] Sim, todos esses esforços, hoje, são necessários para que o futebol-negócio tenha êxito. O futebol deve ser visto como tal (LUIZ GUSTAVO, DIRETOR DE REGISTROS E TRANSFERENNCIA DA CBF. Entrevista em 8-7-2004).

Diante da influência da lógica de mercado sobre o campo do futebol brasileiro, os clubes que, geralmente, obtêm melhores resultados ao serem "eficientes" são os que adotam estratégias de ação consideradas modernizantes e próprias do mundo empresarial - como, por exemplo, estádios-arena de entretenimento - e que buscam, continuamente, novas fontes de financiamento que não sejam apenas as bilheterias. Dessa forma, muitos clubes aderem a contratos de parceria com a mídia - para receberem cotas de televisionamento de seus jogos - e à estratégia de cessão de direitos para a exploração da sua marca.

Salvo aqueles clubes que, devido à conjugação de talentos - como o Santos de Pelé e o Santos campeão brasileiro de 2002 - obtêm sucesso, e depois, provavelmente, vendem seus atletas (ou melhor, "mercadorias"), os demais necessitam se ajustar aos moldes do "mercado". Só assim podem sair de suas crises de performance constatadas sobretudo por baixos desempenhos e pela falta de resultados nos jogos, além de deficiências administrativas na sua gestão -, pois do contrário, correm o risco da obsolescência. Por exemplo, a não observância dessas "questões estratégicas de mercado" pode levar ao rompimento de contratos de parceria.

Primeiro é preciso profissionalizar, para dar seqüência a tais expedientes, pondo dos dois lados da mesa gente que tenha competência específica para levar adiante todas as modernas estratégias. [...] Para que tenhamos fora do campo a mesma eficácia que temos dentro. [...] Hoje, as estratégias de modernização na direção indicada são imprescindiveis à sobrevivência de um clube de futebol, porque o futebol não é mais coisa para amadores. [...] Senão, corre-se o risco de, aos poucos, "matar a galinha dos ovos de ouro." (JUCA KFOURI, JORNALISTA E COLUNISTA DESPORTIVO. ENTREVISTA EM 27-6-2004)

Mudanças no consenso social, em torno da "instituição futebol brasileiro", também podem ser vistas com base nos seguintes indicadores:

- aumento do turnover ou das sucessões;

- fraquezas dos mecanismos de socialização;

- alianças e fusões díspares culturalmente; e

- alta diversificação, dispersão ou diferenciação. 
É inegável a constante entrada e saída de profissionais que atuam na arena futebolística, o que revela turnover e velocidade de sucessões. Nos clubes, por exemplo, a cada mudança de direção e de equipes de trabalho, normalmente, mudam os dirigentes, técnicos, jogadores, fisioterapeutas, massagistas e roupeiros. Somado a isso, a disputa por profissionais credenciados e com competência gerencial, como, por exemplo, dirigentes-executivos, advogados e consultores de marketing esportivo.

Podemos perceber, com base na descrição da transformação da "instituição futebol" e nos discursos prevalecentes nos dados obtidos, que não há consenso quanto aos significados compartilhados no campo do futebol. É perceptível, na história do futebol, o abandono de hábitos e costumes, a adoção de novos elementos e termos no universo do desporto (por exemplo: clientela, mercadoria e produto), o que tende a produzir ou gerar uma deslegitimação de uma atividade institucionalizada e a fraqueza nos mecanismos de socialização. Nesse sentido, houve, e continua havendo, um deslocamento da dimensão valorativa para uma dimensão de negócio na "instituição futebol brasileiro".

Quanto às alianças e fusões díspares culturalmente, e à alta diversificação, dispersão ou diferenciação, pode-se dizer que, diante das transformações no futebol, em face de sua profissionalização, o potencial do mercado que se abriu, sobretudo a partir da década de 1970, provocou ávido movimento de empresas na direção da conquista de direitos de exibição dos espetáculos futebolísticos. Nesse contexto, por exemplo, foi criada, em 14-8-1978, a Globo Esportes, divisão comercial do grupo de Roberto Marinho, com autonomia de compra e venda de conteúdos para a grade de programação, administração de eventos e licenciamento de produtos. Em outro exemplo, a TV Bandeirantes entregou, no fim da década de 1990, o comando da programação de seu departamento de esportes à Traffic, principal agência de marketing esportivo do país. Em fevereiro de 2000, o grupo de investimento norte-americano Hicks, Muse, Tate \& Furst (HMTF) lançou o Panamerican Sports Network (PSN), um canal esportivo por assinatura para a América Latina, transmitido pela TVA, Net e Sky, com o objetivo de explorar esse "negócio".

A estas empresas sucedeu a entrada de instituições financeiras no mundo do futebol. ${ }^{4}$ Segundo destaca Proni (2000), a primeira experiência a registrar foi a associação, em 1997, do Banco Excel-Econômico com o Corinthians (SP) e o Vitória (BA), com contratos de patrocínio que atingiam montantes de R\$5 milhões e R \$ 2 milhões anuais, respectivamente. Em 1998, mais dois contratos são firmados: o investimento de cerca de US\$10 milhões do Banco Opportunity na compra de $51 \%$ das ações do clube Bahia S.A e a parceria do Clube de Regatas Vasco da Gama com o Nations Bank/Banco Liberal (depois comprado pelo Bank of America), para explorar todos os contratos de marketing, licenciamento e de direitos de imagem do time carioca, por meio da Vasco Lic., como ficou conhecida a empresa criada para tal finalidade.

Em um estudo conduzido pelo BNDES (SANTOS et al, 2004), constatou-se que as atividades esportivas em torno do futebol brasileiro caracterizam-se pelo envolvimento de diferentes tipos de empresas:

- empresas de materiais e equipamentos esportivos - como a Nike, Reebok, Adidas, Umbro, Finta, Fila, Speedo, Rhumel, Mizuno, Diadora etc.;

- empresas que investem em patrocínio e marketing esportivo - mediante a exposição de placas publicitárias nos estádios e de sua marca nos uniformes dos jogadores, além de patrocínio a jogadores de grande repercussão, que constituem peça importante da engrenagem do retorno de marketing.

Nesse mesmo estudo foram identificadas:

\footnotetext{
${ }^{4}$ Muitas destas parcerias não perduraram devido a posturas amadoras dos cartolas na administração.
} 
- empresas que trabalham em sistema de co-gestão com clubes - como foi o caso da parceria que envolveu o Palmeiras (SP) e a multinacional alimentícia Parmalat; e

- empresas-time - que surgem a partir da rentabilidade do esporte e de campeonatos organizados, e que são dirigidas por empresários que as administram sob uma ótica empresarial e com fins meramente instrumentais. Este é o caso, por exemplo, de clubes de voleibol e basquete no eixo Rio-São Paulo.

Esses aspectos também surgiram nesta pesquisa na qual se constatou que tais mudanças se refletem na influência das empresas na inserção de novas estruturas e processos organizacionais, com critérios empresariais.

Atualmente, têm sido objeto de discussões e debates na mídia, os interesses e propostas de grandes grupos empresariais nacionais e internacionais em investir em clubes brasileiros, tendo sobre estes influência na gestão do departamento de futebol.

Recentemente, em novembro de 2004, um caso de parceria ou de aliança culturalmente díspare envolvendo o Corinthians (SP) e a Media Sports Investments (MSI) tem sido objeto de discussão na sociedade e na mídia. A MSI, uma grande instituição financeira inglesa que investe no desporto em todo o mundo, propôs ao clube um investimento de US\$35 milhões para pagamento de dívidas e contratação de reforços, com vistas a explorar a marca "Corinthians" por meio da formação de uma empresa licenciada. Porém, o Conselho de Orientação (Cori) do clube sugeriu, para aprovação desse acordo, quatro mudanças no contrato oferecido pela MSI:

- que a negociação fosse feita através do licenciamento da marca "Corinthians", e não através da criação de uma empresa;

- que todo dinheiro enviado pela empresa passasse pelo Banco Central do Brasil, o que forçaria a revelação da origem desses recursos;

- que o clube receba a garantia de cinco bancos, a saber, Credit Suisse, Citibank, Manhattan Chase, JP Morgan e HSBC; e

- que o foro para resolver eventuais problemas jurídicos seja a cidade de São Paulo, pois no contrato inicial não havia indicação de local. Como já se sabe hoje, os conselheiros e o Conselho Deliberativo aprovaram o contrato que une o Corinthians à MSI pelos próximos10 anos, apesar da oposição exercida por uma parte da direção corintiana, que teme perda de autonomia e exerceu até onde pôde, pressões de inércia e de ordem política.

O quadro 3 sintetiza as questões até aqui apresentadas. 


\section{Quadro 3 \\ Fatores intra-organizacionais do processo de desinstitucionalização do futebol brasileiro}

\section{FATORES INTRA-ORGANIZACIONAIS}

Mudanças na distribuição política

Mudanças no consenso social

Mudanças na necessidade funcional

\section{INDICADORES}

Alta diversidade da força de trabalho e realocações de poder

Constante inserção de novos profissionais (como

fisioterapeutas, massagistas, roupeiros, técnicos, advogados e dirigentes profissionais), acompanhada por redistribuição de poder

Crises de performance e risco de obsolescência

Exemplo: baixo desempenho, falta de resultados nos jogos e deficiências administrativas na gestão do clube podem acarretar rompimento de contratos de parceria e obsolescência/falência

Aumento da especificidade técnica e melhor definição das metas

A sobrevivência do clube está ligada à gestão de recursos e a uma visão estratégica de longo prazo (discurso dominante)

Aumento do Turnover ou das sucessões

Entrada e saída constante de profissionais do desporto, sejam técnicos, preparadores físicos, dirigentes de futebol etc.

Fragilidade dos mecanismos de socialização

"Futebol-arte" substituído pelo "futebol-força"

Relações impessoais se sobrepõem às pessoais O "amor à camisa" por parte do jogador dá lugar ao "amor ao dinheiro e à fama"

Alianças e fusões díspares culturalmente e alta diversificação, dispersão ou diferenciação

Entrada de empresas privadas e instituições financeiras como parceiras estratégicas no mundo do futebol, interferindo normalmente na gestão do clube

Fonte: elaborado pelos autores 


\section{As pressões para a desinstitucionalização do futebol brasileiro}

A desinstitucionalização é, portanto, um processo de mudança institucional no qual ocorre a deslegitimação de uma prática outrora institucionalizada, o que não implica a inexistência de instrumentos ou mecanismos de resistência. Tal processo é determinado por um conjunto de pressões desinstitucionalizadoras, a saber: políticas, funcionais e sociais. Pressões de entropia e de inércia moderam o nível em que esse processo ocorre numa instituição.

Com o objetivo de entender o modo como ocorre a quebra de um estado de entropia/equilíbrio institucional, Oliver (1992) propôs um conjunto de preditores/indicadores empíricos de um processo de mudança institucional (leia-se: desinstitucionalização). Mais adiante, procura-se identificar e analisar as pressões que contribuem para o processo de desinstitucionalização do futebol brasileiro.

Os clubes de futebol do Brasil - inicialmente com a Lei Zico e com maior rigor a partir da Lei Pelé -, convivem com um novo paradigma: a passagem de clubes sociais para o status de clubes-empresas. Para exemplificar, temos o fato de que em dezembro de 2004, um dos mais antigos clubes de futebol profissional do estado de Pernambuco, o Sport Club do Recife, realizou eleições para definir seu novo presidente, e o candidato eleito, Luciano Bivar, reiterou em seus discursos a necessidade de, já no ano seguinte, o Sport tornar-se um clubeempresa.

Essa alteração de status e o surgimento de novos clubes, já como empresas, têm mobilizado diversos segmentos da sociedade, federações esportivas, o Estado e outros atores sociais no sentido de ampliar a esfera de atuação de suas ações do âmbito local para o nacional, e deste para o contexto internacional. A Lei Pelé, com suas atualizações, e o Estatuto do Torcedor, por exemplo, exigem uma maior transparência nas gestões dos clubes, com publicações de balanços, pareceres de auditorias independentes e a responsabilidade fiscal dos dirigentes, tudo isso sob a vigilância do Ministério Público.

O futebol transforma-se, assim, amparado pela lei, num campo de investimento valorizado pelo setor privado que, paralelamente, exige a adequação do modelo de gestão dos clubes à exploração econômica e ao modelo empresarial. O futebol sofre mudanças na sua lógica de ação e migra de uma concepção de ócio para uma concepção de negócio sob o amparo das reformas legais, num processo conduzido pelo Estado como agente legislador e regulador. Configuram-se, então, pressões políticas. O uso do futebol como plataforma política, somado às mudanças no marco legal são indicadores dessas pressões de natureza política. A exigência da adequação dos clubes ao modelo de gestão empresarial é um dos exemplos desse cenário.

Além das pressões de ordem política, podemos perceber no campo do futebol brasileiro pressões de natureza funcional por credencialização/profissionalização da gestão do futebol e dos clubes. Têm sido constantes os discursos sobre a necessidade das entidades esportivas contratarem profissionais-executivos e adotarem uma gestão corporativa e estratégica, acompanhada de práticas modernas. Também podem ser vistas, no atual contexto do futebol brasileiro, pressões sociais para que sejam adotadas práticas modernas como o uso/construção de estádios-arena multiuso e, igualmente, pressões pela criação de novos "mercados" de trabalho, via inserção de novos profissionais e diversificação da força de trabalho. Contudo, são observadas resistências ou pressões de inércia:

Deve haver um misto entre profissionalismo e paixão. É preciso ter profissionais, mas não apenas eles. (CARLOS ALBERTO OLIVEIRA, PRESIDENTE DA FEDERAÇÃO PERNAMBUCANA DE FUTEBOL HÁ 10 ANOS. ENTREVISTA EM 7-7-2004)

Os cartolas têm sido o grande entrave. porque não querem perder o privilégio de viver à custa do empobrecimento dos clubes e entidades dirigentes. (JUCA KFOURI, JORNALISTA E COLUNISTA DESPORTIVO. ENTREVISTA EM 27-6-2004) 
É preciso a profissionalização dos clubes, a reciclagem dos cartolas e o afastamento daqueles que não compreendem a nova situação. Mas esse processo de transição exige a ação do Estado e a imposição de limites, tanto aos cartolas - no seu arbítrio dentro de seus clubes - como também à sanha dos agentes do mercado em desejar controlar essas instituições. (ALDO REBELO, MINISTRO DA COORDENAÇÃO POLÍTICA E ASSUNTOS INSTITUCIONAIS DO GOVERNO LULA. ENTREVISTA EM 30-62004)

A estas questões acrescentam-se as pressões de entropia - que, somadas às pressões de inércia, contribuem para moderar o processo de mudança - sobretudo, quanto ao abandono de hábitos e costumes. Nota-se, então, no atual campo do futebol brasileiro, não apenas ações visando à adoção de práticas institucionalizadas no contexto internacional - como a construção de estádios-arena de entretenimento -, mas também focos de resistência, como a atuação dos cartolas. Portanto, são estabelecidas barreiras que impedem a reprodução de normas e valores por meio da dissipação ou rejeição. Isso leva à perda de consenso quanto aos significados compartilhados no campo e revela fraquezas nos mecanismos de socialização, mediante mudanças nos valores sociais e a conseqüente deslegitimação de hábitos e práticas, criando, por conseguinte, uma nova legitimidade. $\mathrm{O}$ futebol brasileiro passa por um processo de desinstitucionalização conduzido por elementos que são preditores a esse processo.

Ao investigar e analisar o campo do desporto na Espanha, Heinemann (1999) verificou que os primeiros clubes e associações emergiram de grupos sociais onde as relações tradicionais - a confiança mútua, o personalismo nas relações e o delineamento não normatizado nem formalmente estabelecido - caracterizavam os relacionamentos, as ações e o cotidiano. A partir do momento em que as organizações do desporto espanhol começaram a formalizar seus procedimentos, incorporaram características centrais da burocracia. Hoje, a divisão das iniciativas dessas organizações tem características da divisão de trabalho tecnocrático, centrado na profissionalização e na especialização, na repartição horizontal e vertical das responsabilidades.

As questões observadas neste artigo podem ser verificadas no campo do futebol brasileiro. O que se percebe aqui, é que o futebol brasileiro, como fenômeno social, esteve até cerca de 1930, fundamentalmente, subordinado à lógica substantiva assentada em valores e tradições. Porém, a necessidade de profissionalização, discurso presente no campo do futebol brasileiro desde meados da década de 1930, aproximadamente, começou a determinar a relação dos jogadores com seus empregadores e a, de certa forma, contribuir para a implantação de elementos antes de domínio exclusivo do âmbito do trabalho, como horários, contratos, sanções e punições inscritas e legitimadas pelas normas escritas.

Essas novas formas de vinculação estão ligadas à perda que se começou a ter do caráter lúdico da prática esportiva e da "instituição futebol brasileiro", e também à incorporação de objetivos organizacionais priorizados pelos dirigentes. Assim como no campo do trabalho, o desporto perde sua dimensão prazerosa. Quer dizer, progressivamente, é construída uma nova lógica de funcionamento das atividades, das regras que lhe dão forma e modificam o comportamento dos atores envolvidos. ${ }^{5}$ Em razão da alteração da lógica de ação, o conjunto de dimensões associadas às características organizacionais tem se afastado dos processos pessoais e informais e procurado buscar, na estruturação das atividades, uma racionalidade dirigida aos fins, uma racionalidade puramente instrumental, como diria Weber (2000).

Atualmente, no universo do futebol brasileiro, os aspectos abordados anteriormente podem ser agrupados sob três tipos de pressão, todas elas condicionadoras de mudanças institucionais: as pressões políticas, as funcionais e as sociais. É o que procura demonstrar a figura 2.

\footnotetext{
${ }^{5}$ Não se está, aqui, criticando a profissionalização em si do futebol brasileiro. O que se procura é apresentar as transformações que ocorrem no cenário futebolístico brasileiro desde a sua profissionalização, principalmente, pela adoção de um modelo empresarial de gestão, em face da sua nova lógica de ação, que é a de mercado.
} 


\section{Figura 2}

\section{Pressões para a desinstitucionalização do futebol brasileiro}

Pressões
políticas

- uso do futebol como plataforma política (Era

Vargas e Ditadura Militar).

- mudanças no marco (Lei

Pelé e Estatuto do Torcedor).

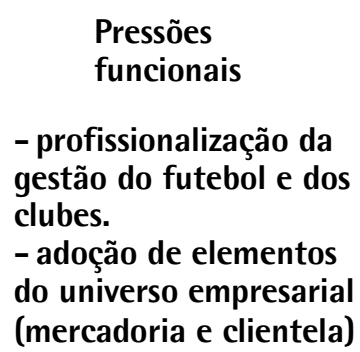

Pressões

sociais

- Para se adotar práticas modernas, como estádios arena multiuso.

- por novos mercados de trabalho no futebol.
- abandono de hábitos e costumes

("futebol -arte" e vinculação do

jogador ao clube por amor)

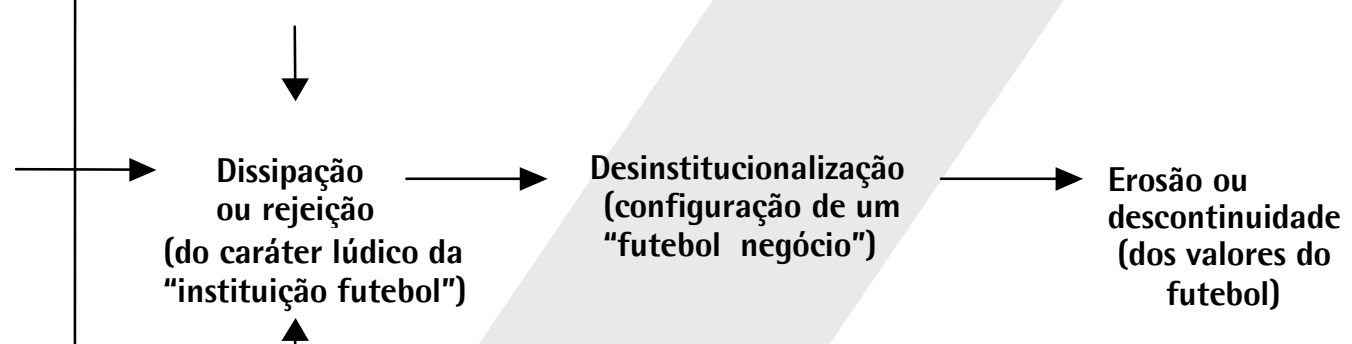

Fonte: elaborado pelos autores

Em que pese a tendência modernizadora em curso, evidenciada no panorama descrito, à medida que o processo avança, fica claro que essa transição não se dá sem resistências. A difusão de uma nova mentalidade de gestão no futebol brasileiro - baseada em princípios próprios da prática mercantil, de transparência de condutas, de redefinição de mecanismos de controle nas entidades desportivas, de cumprimento de obrigações fiscais e previdenciárias - é dificultada pela "ética dual" que caracteriza o sistema futebolístico em nosso país.

Em estudo sobre o futebol como elemento cultural do povo brasileiro, Helal (1997) destacou que a organização do futebol no Brasil tem sido governada pelo poder das relações interpessoais e da troca de favores, e não pelas regras, regulamentos e leis impessoais. Nas suas próprias palavras

Temos aqui uma estrutura dominada pela relação paradoxal entre jogadores profissionais e dirigentes amadores. $O$ dilema brasileiro torna-se evidente, aqui, não somente na relação entre o jogador profissional (moderno) e o dirigente amador (tradicional), mas também no próprio âmbito do universo da classe dirigente, permeado, por um lado, pela política de compensações e troca de favores, e, por outra, pela demanda de profissionalização administrativa, mentalidade empresarial e relações impessoais. [...] "Moderno" significa, aqui, a exigência de um alto grau de profissionalização e comercialização, que objetiva lucrar com o espetáculo futebolístico. "Tradicional” significa uma administração 
baseada mais na paixão, no relacionamento pessoal, troca de favores e na proibição da profissionalização. (HELAL, 1997, p.20 e 33)

Até o momento, na arena do futebol brasileiro, a consolidação de uma nova ética nos "negócios-futebol" ainda enfrenta obstáculos e empecilhos, ou seja, pressões de inércia. Na verdade, a "modernização", da maneira como está proposta, encontra resistências que expõem as contradições e paradoxos existentes. No futebol coexistem o "moderno" e o "tradicional", com os conseqüentes conflitos. Deve ser salientado que são essas tensões entre o "moderno" e o "tradicional" - tão características, aliás, das relações na sociedade brasileira, e que se reproduzem nas relações entre os atores que "habitam" o mundo do futebol - que têm impedido a plena "modernização" de sua estrutura no país. É a prevalência, até o momento, da estrutura tradicional de poder em contraposição a uma realidade legal e conjuntural que impulsiona o futebol para a busca de um novo status.

\section{As estratégias modernizantes no atual contexto do futebol brasileiro}

Nos seus primeiros anos, essa prática desportiva constituía uma forma de recreação e de lazer para os seus participantes, além de uma busca de construção de laços de identidade coletiva entre os indivíduos. Foi inicialmente realizada em campos de várzea e depois, também, em grandes estádios. De uma comunicação/transmissão outrora realizada exclusivamente por rádios, com horários devidamente acertados entre os clubes, passou-se para uma transmissão via canais de televisão que controlam a determinação dos horários dos jogos. De relações de ordem pessoal, características do cenário lúdico do futebol, migrou-se para um contexto de impessoalidade e de práticas gerenciais comerciais. A jogadores com uma vinculação aos clubes marcada pelo amor à camisa sucederam indivíduos que definem suas atuações em função das vantagens contratuais oferecidas. Hoje, configura-se adoção de um modelo empresarial de gestão.

Percebe-se que, atualmente, o futebol representa um negócio potencialmente rentável que tem imposto outros procedimentos à formação de atletas, à relação contratual entre atleta e clube, às condutas dos torcedores nos estádios e ao gerenciamento das entidades esportivas. As mudanças no campo do futebol brasileiro contribuem, de certa forma, para a (re)modelagem do futebol, pois as organizações desportivas incorporam novos significados aos seus agentes e instituições, frutos da ampliação de uma nova lógica de ação, a de mercado, que se reflete em diversos elementos como o torcedor, o jogador, o jogo, o estádio e os relacionamentos. Agora, o ambiente técnico, de certo modo imperceptível na origem do futebol brasileiro, exerce maior influência sobre o contexto dessa prática desportiva. O torcedor, outrora percebido como devedor eterno de sua devoção ao clube, por seu amor à camisa, é encarado como um "mercado consumidor" com potencial de compra e necessidades a serem atendidas. O jogo, antes uma atividade de lazer, de ócio e de liberação de tensões do trabalho, transforma-se em "espetáculo" e oportunidade de negócio, tendo como "mercadoria" os jogadores. Nesse "negócio" extremamente lucrativo, que envolve entre outros agentes a mídia como elemento central, os clubes encontram uma forma de ampliar suas fontes de financiamento e a exposição da sua imagem.

Por sua vez, a crescente racionalização contribui para a incorporação de novos agentes no âmbito dos negócio dos clubes de futebol. Empresas de marketing esportivo, instituições financeiras, organizações privadas interessadas no retorno da marca e outros clubes de futebol surgem com o intuito de estabelecer ações de natureza comercial e maximizar seu retorno financeiro, o que demonstra que o caráter de negócio assume uma posição determinante. Nesse sento, ele tende a se consolidar a partir:

- da construção de estádios-arena de entretenimento;

- da ampliação das fontes de financiamento (além da bilheteria) através de contratos com a televisão, da cessão de direitos sobre a marca do clube e de direitos federativos sobre o atleta, além do aluguel de espaços do clube;

- da parceria e marketing esportivo; 
- de sistemas de planejamento e gestão de recursos; e

- do credenciamento dos profissionais.

As arenas multiuso ${ }^{6}$ são instalações nas quais, além de apresentações esportivas, são realizados concertos, shows, exposições, congressos, cultos etc. O clube funciona como uma "âncora" para a arena, que é vista como centro de lazer, com lojas, restaurantes e bares abertos ao público externo. Algumas oferecem serviços de hotelaria, enquanto outras funcionam como um shopping center, como é o caso do clube inglês Manchester United.

No Brasil, o primeiro estádio-arena foi o do Clube Atlético do Paraná, muito embora ainda não tenha sido plenamente aproveitado. Destacam-se também a reforma, com a incorporação de tecnologias do estádio-arena, no estádio do São Paulo Futebol Clube, o Morumbi, e o novo Arena Joinville, do Joinville Sport Club.

A construção de estádios-arena representa uma estratégia de ação auxiliar para o retorno dos torcedores aos estádios e de incremento do rendimento dos clubes e das empresas parceiras envolvidas. Essa estratégia tem sido apoiada por regulações governamentais que criaram as condições para o seu desenvolvimento. Entretanto, há resistências, e estas consistem no questionamento ao tratamento dispensado aos torcedores, que os reduz a meros consumidores, conforme sinaliza o seguinte discurso:

O estádio moderno que nós defendemos, confortável, não vai resolver essa relação. Ele pode até resolver a relação do torcedor-consumidor, mas o mercado jamais deve se esquecer de que antes de ser consumidor, ele é, em primeiro lugar, torcedor, e que tentar reduzi-lo à condição de consumidor pode destruir os dois entes. Destruir o torcedor é destruir o consumidor que anda junto com ele. (ALDO REBELO, MINISTRO DA COORDENAÇÃO POLITICA E ASSUNTOS INSTITUCIONAIS DO GOVERNO LULA. ENTREVISTA EM 30-6-2004)

Este posicionamento sinaliza a existência de pressões de entropia, sobretudo, no que diz respeito ao abandono de hábitos e costumes da "instituição futebol brasileiro". O "futebol-arte" no qual prevaleciam o espetáculo, a recreação e as relações pessoais entre os participantes, cede lugar ao "futebol-negócio", baseado em relações impessoais e comerciais, no qual os clubes procuram explorar suas "mercadorias-jogadores" e seus potenciais "consumidores-torcedores" através da criação dos espaços de entretenimento.

A principal fonte de financiamento das atividades clubísticas sempre foi a bilheteria. Porém, ante à expansão da lógica de mercado ampliaram-se as fontes de receitas dos clubes através das parcerias com as principais redes de televisão aberta. Os contratos abrangem uma participação média de $70 \%$ das receitas dos clubes, configurando, hoje, sua principal fonte de recursos e uma forma de dependência externa.

Os clubes realmente têm que ter mais atenção às novas fontes, pois as fontes antigas não são mais suficientes para pagar os jogadores, técnicos etc. O clube precisa se inserir nessa "roda viva" para poder sobreviver. (LUIZ GUSTAVO, DIRETOR DE REGISTROS E TRANSFERENCIA DA CBF. ENTREVISTA EM 8-7-2004)

Em que pese os rendimentos oriundos da televisão, essas parcerias têm apresentado aspectos negativos que constituem entraves ao "processo comercial" do "produto-futebol", tais como:

\footnotetext{
${ }^{6}$ Os EUA foram pioneiros na construção de arenas multiuso para combater a violência nos ginásios e estádios, transformando assim os eventos em grandes espetáculos. Podemos citar o Fleet Center em Boston, o United Center em Chicago, o Madson Square Garden em Nova York, o Microsoft em Seattle e o Miami Arena em Miami. No Canadá, o Skydrome Stadium, na Coréia do Sul, o Sarjic Main Stadium, e na Europa, o Oberhausen na Alemanha, o Nymex Manchester na Inglaterra e o Amsterdan Ájax na Holanda (José Joaquim Azevedo, consultor esportivo e ex-vice-presidente da Federação Pernambucana de Futebol, numa entrevista em 1-7-2004).
} 
- a determinação de horários subordinados à grade de programação das emissoras, o que influencia os horários e os programas de treinamento;

- a fixação dos valores de contratos de cotas diferenciadas em função do número de torcedores e da representatividade dos clubes e dos campeonatos; e

- a transmissão direta dos jogos para a praça onde estes estão sendo realizados, interferindo na presença de torcedores nos estádios.

O aluguel de seus espaços também é uma importante fonte de receitas para os clubes, principalmente, pela publicidade estática nos estádios. Por sua vez, os clubes com grande contingente de torcedores e expressiva representatividade no cenário nacional já vislumbram (e alguns até já adotam) uma política de cessão de direitos sobre a marca, o que igualmente se torna importante fonte de receita.

Como muitos dos clubes de futebol ainda não conseguem gerar receitas com seu estádio ou com sua marca, os dirigentes de futebol ficam reféns da significativa receita proveniente da venda de direitos de exibição para a televisão. O que fazem então os grandes clubes, representados pelo Clube dos Treze? Na guerra pela audiência e pelas milionárias cotas de publicidade - reforçadas em grandes campeonatos, como a Copa do Mundo -, esses clubes estimulam a criação de mais competições, para elevar a receita com os direitos de transmissão. Ao mesmo tempo, procuram investir na instalação de centros de treinamento (CT), visando formar atletas e negociá-los através de vultosos contratos, o que também é uma das grandes fontes de recursos dos clubes. É quando, então, ocorre a cessão dos direitos federativos de atletas, pois embora não mais exista o vínculo do passe, os contratos podem ter validade de cinco anos, período em que os clubes ficam com os direitos federativos dos seus atletas, inclusive com cláusula penal estipulada, a ser paga em caso de transferência destes durante a vigência do contrato.

Ultimamente, os clubes vem buscando novas alternativas de receita. O "Canal do futebol" e a "Timemania", nova loteria esportiva, são algumas das novas opções que têm sido objeto de discussão. Outra alternativa em análise pelo governo é a incorporação, pelo Estatuto do Esporte, em tramitação no Congresso, de um projeto de lei de incentivo fiscal.

Todos esses esforços visam tratar o futebol como negócio, e para tal tem que haver uma estreita relação com o marketing. Trata-se de um negócio que, bem administrado, poderá render bons frutos, através de parcerias que usarão as marcas com contratos de merchandising, expondo-as na gigantesca vitrine dos clubes. É esse o discurso dominante no universo do futebol brasileiro, constatado nos dados secundários e nas entrevistas-chave.

Na relação de parceria, as empresas cobram e exigem do clube que este tenha jogadores de boa visibilidade, que seja um clube organizado dentro e fora do campo. Assim, terão êxito no campeonato e proporcionarão boa exibição na mídia, da marca. (LUIZ GUSTAVO, DIRETOR DE REGISTROS E TRANSFERENNCIA DA CBF. ENTREVISTA EM 8-7-2004)

Outra evidência do incremento da lógica do mercado no futebol brasileiro é o desenvolvimento do marketing esportivo, que vem se revelando um instrumento fundamental no crescimento do setor. Os eventos desportivos agregam valores positivos aos produtos e serviços das empresas, com resultados inestimáveis em termos de imagem institucional. Assim, hoje em dia, as parcerias de marketing esportivo são feitas com fornecedores de material esportivo, com o uso da marca do clube em produtos e até a co-gestão do futebol. ${ }^{7}$ Os principais objetivos dos parceiros envolvidos no futebol brasileiro são: a oportunidade de negócio, a participação na gestão do clube e a melhora da imagem institucional.

\footnotetext{
${ }^{7}$ Aqui, a co-gestão envolve a participação de empresa parceira na administração do departamento de futebol de um clube (LOIS; CARVALHO, 1998).
} 
Segundo Proni (2000), pela ação de distintos agentes, a lógica do mercado tem dado o tom da modernização em curso no futebol brasileiro. Para exemplificar, cabe citar o primeiro caso de co-gestão esportiva no futebol brasileiro, concretizado em 1992 e que envolveu a multinacional italiana Empresa Alimentícia Parmalat e a Sociedade Esportiva Palmeiras, de São Paulo.

A Parmalat começou a investir em esporte em 1975, quando patrocinou a final da Copa Européia de Esqui. Em 1996, já patrocinava clubes como o Benfica (Portugal), o Boca Juniors (Argentina) e o Peñarol (Uruguai). No Brasil, a empresa iniciou o investimento nessa estratégia, pelo futebol, a partir de 1992. O clube escolhido foi o Palmeiras (SP), com o qual a empresa não desenvolveu apenas um simples patrocínio esportivo. ${ }^{8}$ Para o diretor de esportes do Palmeiras-Parmalat, José Carlos Brunoro, a co-gestão não se resumia à injeção de recursos para fortalecer o departamento de futebol. "A parceria Palmeiras-Parmalat foi o paradigma para esse tipo de estratégia modernizante. Foi o marco inicial. (LUIZ GUSTAVO, DIRETOR DE REGISTROS E TRANSFERÊNCIAS DA CBF. ENTREVISTA EM 8-7-2004)

A empresa comprometia-se em oferecer "know-how", informações estratégicas, técnicas de negociação que contribuíssem para a eficácia de sua gestão. Assim, este tipo de parceria significou o paradigma da gestão profissional a ser seguida pelos demais clubes.

A parceria entre o Palmeiras e a Parmalat proporcionou enorme sucesso em termos de retorno da exposição para seus parceiros e despertou o interesse de muitas empresas interessadas em explorar a projeção que o futebol pode conferir a uma marca. Quando a parceria começou, em 1992, a Parmalat tinha um faturamento bruto de US\$ 220 milhões no Brasil. Nos anos seguintes, ao mesmo tempo que vinham os títulos, cresciam as vendas dos produtos da empresa. Em 1996, o faturamento bruto alcançou US\$ 1,2 bilhão. (PRONI,2000, p.207)

Essa parceria é tida como exemplo de gestão de "sucesso" que impõe o paradigma da necessidade de "oxigenar" a gestão do futebol com dirigentes formados, para que se tenha "fora de campo a mesma eficácia que normalmente se tem dentro dele". Tal fato demonstra de, certa forma, o discurso dominante de que é preciso profissionalizar, para que as estratégias modernizantes sejam postas em prática com mais eficiência, por indivíduos que tenham "competência" específica para levar adiante esses "negócios", pois o investidor/parceiro quer resultado "dentro e fora do campo".

Nesse cenário há que se destacar a entrada de instituições financeiras no mundo do futebol. A primeira experiência foi a associação, em 1997, do Banco Excel-Econômico com o Corinthians e o Vitória, com contratos de patrocínio que atingiam $\mathrm{R} \$ 5$ milhões e $\mathrm{R} \$ 2$ milhões anuais, respectivamente. Em 1998 foram firmados outros dois contratos milionários: o investimento de cerca de US\$10 milhões do Banco Opportunity na compra de $51 \%$ das ações do Bahia S.A. e a parceria do Vasco da Gama com o Nations Bank/Banco Liberal, mais tarde comprado pelo Bank of America, para explorar todos os contratos de marketing, licenciamento e de direitos de imagem do time carioca, por meio da Vasco Lic., como ficou conhecida a empresa criada especialmente para isso (PRONI, 2000).

Os clubes ainda têm um caminho a percorrer para o ambiente acionário e societário, diferente de casos de co-gestão - direitos "formais" e patrocínio que já têm experiência suficiente para uma boa administração. (JOSÉ CARLOS BRUNORO, CONSULTOR EM MARKETING ESPORTIVO E EXDIRETOR DO DEPARTAMENTO DE ESPORTES DO PALMEIRAS/PARMALAT. ENTREVISTA EM 15-8-2004)

\footnotetext{
${ }^{8}$ Por patrocínio esportivo leia-se a destinação de uma verba para um atleta, equipe, clube ou entidade esportiva, em troca da exposição da marca nas camisas ou em placas no campo, por exemplo (LOIS; CARVALHO, 1998).
} 
Como consequiência da obrigatoriedade legal da transformação dos clubes em empresas, aprovada pela Lei Pelé em 1998 e mantida até 2000, quando tal exigência se tornou facultativa, os clubes experimentaram diferentes esquemas de parcerias. Alguns, como o Vasco da Gama, terceirizaram seus departamentos de futebol, enquanto outros cederam o controle acionário a empresas privadas, como o Bahia. Há também o caso dos que iniciaram suas atividades precisamente nesse período, como o Intercontinental, de Pernambuco (MAGALHÃES FILHO, 2003).

Nesse contexto de mudanças, principalmente a partir do final da década de 1990, empresas multinacionais começaram a assumir a condição de investidores no mercado futebolístico brasileiro, já não somente como patrocinadores, mas com o objetivo de dividir os lucros do negócio. Proni (2000) salienta que as mais notórias experiências do gênero envolveram duas das maiores empresas mundiais de marketing esportivo, a Hicks Muse Tate \& Furst (HTMF) e a International Sports Leisure (ISL), recentemente liquidada por processo de falência. Por $\mathrm{R} \$ 53$ milhões, a construção de um estádio multiuso e 15\% de participação na Corinthians Licenciamento Ltda., a HTMF assumiu o controle do departamento de futebol do clube por 10 anos. Essa parceria terminou por causa da gestão amadora do clube, segundo afirma Proni (2000). Daí, o discurso prevalecente pela profissionalização da gestão.

O futebol brasileiro continua produzindo talentos dentro do campo. Entretanto, no seu gerenciamento é totalmente amador, dominado pela paixão, originando, assim, a falta de credibilidade para a obtenção de incentivos e investimentos no setor. O clube tem que se profissionalizar em todos os níveis, através de executivos da mais alta qualidade. Não existe nenhuma possibilidade de sobrevivência dos clubes, se não mudarem as suas estratégias de gestão. (JOSÉ JOAQUIM AZEVEDO, CONSULTOR ESPORTIVO E EX-VICE-PRESIDENTE DA FEDERAÇÃO PERNAMBUCANA DE FUTEBOL. ENTREVISTA EM 1-7-2004)

No final da década de 1990, por valores que chegavam a $\mathrm{R} \$ 137$ milhões, mais um estádio com capacidade para 60 mil torcedores e $25 \%$ de participação nos lucros, a ISL passou a explorar a marca mais valorizada do futebol brasileiro durante 15 anos, a do Clube de Regatas Flamengo. Na sequiência, firmaram contratos semelhantes o Grêmio, de Porto Alegre (com a ISL), e o Cruzeiro, de Belo Horizonte (com a HTMF), além do Santos e do Atlético mineiro (com o grupo CIEOctagon). Tais contratos, porém, não tiveram continuidade.

$\mathrm{O}$ discurso transcrito adiante sintetiza os argumentos do universo do futebol quanto à necessidade de se buscar profissionais-executivos que façam uso de modernos sistemas de planejamento como controles estatísticos, balanços etc. Tudo isso, na verdade, com o intuito de dar um direcionamento às demais estratégias apresentadas.

Um clube de futebol não poderá sobreviver no atual momento e no futuro sem um planejamento e, sobretudo, uma linha delineada de gestão de recursos, através de um orçamento bem elaborado, onde serão contidas as fontes de usos e fontes dos recursos a serem aportados e gastos, com critérios empresariais e profissionais. Para que tal fato possa acontecer, será necessário a transformação, principalmente, do departamento de futebol em empresa, com uma gestão profissional, através de executivos preparados para dar a dinâmica necessária ao planejamento programado. (JOSÉ JOAQUIM AZEVEDO, CONSULTOR ESPORTIVO E EX-VICE-PRESIDENTE DA FEDERAÇÃO PERNAMBUCANA DE FUTEBOL. ENTREVISTA EM 1-7-2004)

Porém, como em todo processo de mudança, há resistências. Nas palavras do ministro Aldo Rebelo:

Um clube deve se apoiar numa estratégia de gestão atualizada e com grande apoio mercadológico, mas não pode deixar de cultivar o seu aspecto de uma instituição de massa, de um elemento da cultura do povo, e esse aspecto não pode ser cultivado ou mantido apenas com medidas que atendam às necessidades do mercado. (ALDO REBELO, MINISTRO DA COORDENAÇÃO POLÍTICA E ASSUNTOS INSTITUCIONAIS DO GOVERNO LULA. ENTREVISTA EM 30-6-2004) 
O que se percebe pelos dados coletados e analisados nesta pesquisa é que, no universo do futebol brasileiro, ainda há um certo dilema entre a preservação dos laços sociais e comunitários e a cedência à lógica de mercado. Parece haver uma tentativa de se resguardar alguns valores fundamentais mas, também, dar mais transparência aos "negócios". O futebol parece estar num processo de desinstitucionalização ao qual resistem os agentes tradicionais (como os "dirigentes cartolas"), os torcedores, os valores tradicionais etc., o que parece ser um dos motivos para sua lenta reinstitucionalização.

\section{Considerações finais}

Neste artigo se procurou evidenciar até que ponto a expansão da lógica de mercado e a adoção de um modelo empresarial de gestão conduzem um processo de desinstitucionalização do futebol no Brasil. Percebeu-se que a ação instrumental, baseada no cálculo utilitário das conseqüências - e que tem se legitimado em toda a sociedade - está presente de maneira decisiva nas organizações futebolísticas, onde a noção de maximização do retorno sobre o "investimento" assume natureza imperativa.

Até meados do século XX, o futebol brasileiro esteve fundamentalmente assentado numa lógica de ação substantiva, pela qual prevaleciam as relações pessoais e não normatizadas, e através da qual o discurso dos dirigentes baseava-se no amor ao clube e na paixão pela camisa. Elementos de seu ambiente institucional, tais como hábitos, valores, costumes e tradições ditavam as "regras do jogo", sobrepondo-se aos elementos do seu ambiente técnico. Assim esteve institucionalizado o futebol brasileiro.

Por meio do discurso e das ações em torno da "profissionalização" e subseqüente "modernização" do futebol no Brasil, presentes desde a década de 1970, tiveram início ações de caráter mercantil nessa prática desportiva. Paulatinamente, na arena do desporto brasileiro, passaram a ser comercializados inúmeros produtos e serviços. Além disso, às organizações futebolísticas, foram agregadas, como "parceiros", instituições financeiras e empresas de marketing esportivo dispostas a investirem em clubes com grande representatividade nacional e torcida numerosa, visando ganhos de mercado e melhor imagem institucional.

Nos últimos anos, a mercantilização do futebol, criou uma situação em que grande fluxo de capitais envolveu a atividade. Seja por meio da venda de direitos de uso da marca de seleções e clubes ou da imagem de jogadores para empresas, ou da venda dos direitos de transmissão de jogos por televisão, rádio e Internet, sem contar as transferências de jogadores entre clubes e entre países, tudo isso, somado, superou em muito a antiga fonte de recursos que era a renda obtida com a venda de ingressos nos estádios.

Grandes grupos de investidores, fundos de investimentos multinacionais, inclusive, atraídos pelo potencial econômico do futebol, vêm entrando no setor, patrocinando e tornando-se co-administradores de clubes e jogadores. Ademais, um clube de futebol, hoje, requer altos salários para os seus jogadores, estruturas dispendiosas, como os centros de treinamento, local para a concentração da equipe, estruturas de recursos humanos e uma comissão técnica especializada e numerosa.

Em razão da alteração da lógica de ação, o conjunto das ações e das características das entidades futebolísticas brasileiras incorporaram elementos comuns ao universo empresarial. As relações estão centradas na impessoalidade; são criadas e desenvolvidas estratégias de controle que assegurem o alcance dos objetivos e estruturadas ações mercantis modernizantes. A gestão legítima, agora, é a que ocorre segundo moldes empresariais.

A influência e a expansão da lógica de mercado no campo do futebol brasileiro induzem a adoção de elementos do universo empresarial na administração das organizações esportivas. Agora, são os conceitos e as práticas empresariais que vigoram e ditam "as regras do jogo" e as novas bases de legitimação. São eles também que orientam o discurso dos dirigentes, que vêem no futebol uma oportunidade de promoção e de "grandes negócios". 
Configura-se, então, um processo de desinstitucionalização e cria-se uma nova legitimidade. As pressões políticas, sociais e funcionais pela mercantilização do futebol brasileiro e a conseqüente fragmentação normativosocial contribuíram para a perda do consenso cultural entre os participantes e as instituições. A alteração de normas e valores institucionais e as mudanças nas interações entre os parceiros nesse campo contribuem para a erosão e a dissipação de normas e práticas institucionalizadas, implicando uma nova legitimidade, que é a dos "negócios". A legitimação de uma nova lógica de referência traz consigo novos atores, procedimentos e categorias antes exclusivas do ambiente empresarial, como mercadoria, clientela, eficiência, eficácia, resultado e competitividade.

Quanto ao papel do Estado, é inegável sua importância na configuração desse cenário, pois trata-se de um importante agente regulador e legitimador dessa mudança institucional. Diante da importância econômica atribuída ao futebol brasileiro, são promulgadas leis visando à institucionalização do clube-empresa, de uma cultura de negócio e de uma gestão empresarial. Esse cenário, porém, enfrenta a resistência de agentes tradicionais como os "dirigentes cartolas", torcedores e elementos de tradição dos clubes que, somados, apontam motivos para que uma possível reinstitucionalização ainda não ocorra.

Nesse ponto, é importante advertir que este artigo não defende a eliminação das organizações empresariais, nem a extinção de sua participação no cenário desportivo brasileiro. Os argumentos aqui apresentados são críticas às organizações da produção e do trabalho como razão de ser da vida humana.

É verdade que ainda podem existem focos de lazer, ócio e diversão em jogos realizados em campos de várzea. Porém, são casos que se limitam a zonas periféricas e com pouca visibilidade no cenário nacional, e que não atraem os olhares e os investimentos. Acredita-se que este estudo relata a inserção e expansão da lógica de mercado num setor nunca antes dominado por tal ação instrumental. A "mão invisível do mercado" está cada vez mais visível. A empresa torna-se elemento central e as dimensões substantivas da vida social são substituídas por imperativos econômicos e financeiros.

O estudo e a pesquisa realizada sobre esse fenômeno social - a mercantilização do futebol brasileiro - levam seus autores a fazerem algumas considerações.

No processo de construção social, há contradições, dilemas, rupturas, inconsistências, jogos de poder e a mediação de interesses, e nele, arranjos sociais são construídos na interação entre as pessoas dentro de contextos sociais. Dessa forma, admitir que os indivíduos constroem significados implica admitir que agem conforme sua interpretação da realidade, e que podem limitar ou ampliar o escopo dos processos que ocorrem nas organizações, uma vez que as estruturas refletem também valores e interesses. Portanto, passam a refletir também as relações de poder entre indivíduos e grupos, levando a consideração de que as organizações devem ser entendidas como instrumentos de poder.

Estamos numa sociedade em que todas as esferas da vida social, e o próprio homem, estão se tornando recursos e mercadorias. O capital governa o nosso mundo. Atividades substantivas como o desporto e a cultura estão abandonando o seu caráter original: perde-se o lúdico e o livre; o que não tinha obrigatoriamente um fim e um resultado final, hoje é competição e oportunidade de negócios. Pergunta-se então: como ocorrem as relações de poder no contexto da apropriação pelo mercado das instituições desportivas, na construção de seus valores ou em respostas às demandas da sociedade? Quais as implicações institucionais e sociais da mercantilização do futebol de massas? Quais o impacto social da apropriação pelo mercado das instituições de lazer, da arte e da cultura? É possível o resgate da dimensão substantiva nas relações sociais e organizacionais e o retorno da centralidade do homem?

Este artigo não tem respostas conclusivas, mas tem como propósito inquietar, gerar mal-estar e não deixar que esses temas se naturalizem e adormeçam na nossa consciência deo investigadores e atores sociais. 


\section{Referências}

ANDRADE FILHO, J. C.; MACHADO-DA-SILVA, C. L. Mudança ambiental e posicionamento estratégico em organizações: análise de três instituições de ensino superior. In: ENCONTRO NACIONAL DE ESTUDOS ORGANIZACIONAIS, 2., 2002, Recife. Anais... Recife: Observatório da Realidade Organizacional: Propad/UFPE, Anpad, 2002. 1 CD-ROM.

BECKERT, J. Agency, entrepreneurs and institutional change: the role of strategic choice and institutionalized practices in organizations. Organization Studies, v.20, n.5, p.777-799, 1999.

BERGER, P. L.; LUCKMANN, T. A construção social da realidade: tratado de sociologia do conhecimento. Petrópolis: Vozes, 1976.

CARVALHO, C. A. P. Novas formas de estrutura e gestão: um estudo sobre as organizações do campo do desporto. Projeto CNPq, 2001.

Configuração do campo da cultura no contexto da incorporação da lógica mercantil e os novos atores organizacionais. Projeto CNPq, 2003

; GONÇALVES, J. C. S.; ALCÂNTARA, B. C. O lúdico, o profissional e o negócio no futebol. In: ;VIEIRA, M. M. F. (Org.). Organizações, cultura e desenvolvimento local: a agenda de pesquisa do Observatório da Realidade Organizacional. Recife: Edufepe, 2003. p.235254.

; VIEIRA, M. M. F. Contribuições da perspectiva institucional para a análise das organizações: possibilidades teóricas, empíricas e de aplicação. In:_____ (Org.). Organizações, cultura e desenvolvimento local: a agenda de pesquisa do Observatório da Realidade Organizacional. Recife: Edufepe, 2003. cap.1, p.23-40.

CBF NEWS - o site oficial da Seleção Brasileira de Futebol. História do futebol brasileiro: o nascimento de uma paixão. Rio de Janeiro: CBF, 2004. Disponivel em: <http://www.cbfnews.bol.com.br/historia/hist_01.jhtm>. Acesso em: 20 mar. 2004.

CLEMENS, E. S.; COOK, J. M. Politics and institutionalism: explaining durability and change. Annual Review of Sociology, v.25, p.441-466, 1999.

COOPER, D. R.; SCHINDLER, P. S. Métodos de pesquisa em administração. 7.ed. Porto Alegre: Bookman, 2003.

DACIN, M. T. The embeddedness of organizations: dialogue \& directions. Journal of Management, v.25, n.3, p.317-356, May/June 1999.

DAVIS, G. F.; DIEKMANN, K. A.; TINSLEY, C. H. The decline and fall of the conglomerate firm in the 1980s: the deinstitutionalization of an organizational form. American Sociological Review, v.59, n.4, p.547-570, August 1994.

ELIAS, N.; DUNNING, E. Deporte y ocio en el proceso de la civilizacion. 2.ed. México: Fondo de Cultura Económica, 1995.

GONÇALVES, J. C. S.; CARVALHO, C. A.; ALCÂNTARA, B. C. Transformações no contexto do futebol brasileiro: o Estado como agente de mudança. In: ENCONTRO NACIONAL DE ESTUDOS ORGANIZACIONAIS, 3., 2004, Atibaia, SP. Anais... São Paulo: FGV/Easp, 2004. 1 CD-ROM.

; MAGALHÃES FILHO, P. A. 0.; ALCÂNTARA, B. C. S. Do ócio ao negócio: a expansão da lógica de mercado no futebol de Pernambuco. In: COLÓOUIO INTERNACIONAL SOBRE PODER LOCAL, 9., 2003, Salvador. Anais... Salvador: Nepol/UFBA, 2003. 1 CD-ROM.

GREENWOOD, R.; HININGS, C. R. Understanding radical organizational change: bringing together the old and the new institutionalism. Academy of Management Review, v.21, n.4, p.1022-1047, 1996.

HEINEMANN, K. Sociologia de las organizaciones voluntarias: el ejemplo del club deportivo. Valencia : Tirant lo Blanch, 1999.

HELAL, R. Passes e impasses: futebol e cultura de massa no Brasil. Petrópolis: Vozes, 1997.

JEPPERSON, R. L. Institutions, institutional effects and institutionalism. In: POWELL, W. W.; DIMAGGIO, P. J. The new institutionalism in organizational analysis. London: University of Chicago Press, 1991. cap.6, p.143-163.

LOIS, N. C.; CARVALHO, S. A co-gestão esportiva no futebol: o caso Juventude-Parmalat. Passo Fundo: Ediupf, 1998. 
MAGALHÃES FILHO, P. A. O. A configuração organizacional dos clubes de futebol do Estado de Pernambuco e a expansão da lógica de mercado. 2003. 140f. Dissertação (Mestrado em Administração) - Universidade Federal de Pernambuco, Recife, 2003.

MARCONI, M. A.; LAKATOS, E. M. Técnicas de pesquisa: planejamento e execução de pesquisas, amostragens e técnicas de pesquisa, elaboração, análise e interpretação de dados. 2.ed. São Paulo: Atlas, 1990.

MELO FILHO, A. Futebol profissional: utopias e realidades da nova legislação. Revista Brasileira de Direito Desportivo, v.4, p.93-133, 2004. MEYER, J. W.; ROWAN, B. Institutionalized organizations: formal structure as myth and ceremony. In: POWELL, W. W.; DIMAGGIO, P. J. The new institutionalism in organizational analysis. London: University of Chicago Press, 1991. p.41-62.

OLIVER, C. The antecedents of deinstitucionalization. Organization Studies, v.13, n.4, p.563-588, 1992.

PINTO, M. S. L.; OLIVEIRA, R. R. Análise do momento crítico do setor elétrico brasileiro e suas variações institucionais. In: ENCONTRO ANUAL DA ASSOCIAÇÃO NACIONAL DOS PROGRAMAS DE PÓS-GRADUAÇÃO EM ADMINISTRAÇÃO, 26., 2002, Salvador. Anais... Rio de Janeiro: Anpad, 2002. 1 CD-ROM.

PRONI, M. W. A metamorfose do futebol. Campinas: Unicamp, 2000.

ROWAN, B. Organizational structure and the institutional environment: the case of public schools. Administrative Science Quarterly, v.27, n.2, p.259-280, 1982.

SANTOS, A. M. M. M. et al. Esportes no Brasil: situação atual e propostas para desenvolvimento. Rio de Janeiro: BNDES, 2004. Disponível em: <http://www.bndes.gov.br/conhecimento/bnset/esporte.pdf>. Acesso em: 5 jun. 2004.

SCOT, W. R. Conceptions of environments. In: ; TERRELL, D. L. Organizations: rational, natural and open systems. 4.ed. London: Prentice Hall, 1998. cap.6, p.123-217.

; MEYER, J. W. The organization of societal sectors: propositions and early evidence. In: POWELL, W. W.; DIMAGGIO, P. J. The new institutionalism in organizational analysis. London: University of Chicago Press, 1991. cap.5, p.108-142.

SELZNICK, P. A liderança na administração. Rio de Janeiro: Fundação Getúlio Vargas, 1971. cap.5, p.115-132.

SEVCENKO, N. Futebol, metrópoles e desatinos. Revista USP, São Paulo, n.22, p.30-37, jun./ago. 1994. Dossiê Futebol.

SLACK, T. Organization theory and the management of sport organizations. In: Understanding sport organizations: the application of organization theory. United States: Human Kinetics, 1997. cap.1, p.1-16.

TRIVIÑOS, A. N. S. Introdução à pesquisa em ciências sociais: a pesquisa qualitativa em educação. São Paulo: Atlas, 1995.

TUCHMAN, G. Historical social science: methodologies, methods and meanings. In: DENZIN, N. K.; LINCOLN, Y. S. Handbook of qualitative research. United States: Sage Publications, 1994. cap.19, p.306323.

VIEIRA, M. M. F.; CARVALHO, C. A. Campos organizacionais: de wallpaper à construção histórica do contexto de organizações culturais em Porto Alegre e em Recife. In: ENCONTRO ANUAL DA ASSOCIAÇÃO NACIONAL DOS PROGRAMAS DE PÓS-GRADUAÇÃO EM ADMINISTRAÇÃO, 27., 2003, Atibaia, SP. Anais... Rio de Janeiro: Anpad, 2003. 1 CD-ROM.

WEBER, M. Economia e sociedade: fundamentos da sociologia compreensiva. 3.ed. Brasilia: Editora da UnB, 2000. v.1. 